Opinion

\section{Determination of calcium in the tooth structure by using flame emission spectrophotometer}

\author{
Şükrü Kalaycı* \\ Department of Chemistry, Gazi University, Ankara, Turkey
}

\section{Introduction}

Calcium is the most common element in the tooth's structure. In addition, calcium is one of the elements that are effective in maintaining dental health. As a result of calcium deficiency, the tooth becomes brittle and begins to rot. Calcium deficiency usually occurs in acidic beverage consumption and during canal treatment. A study was conducted to determine the degree of calcium removal in the root canal dentin after 17\% EDTA, 17\% EGTA, 15\% EDTAC and 1\% tetracycline-HCl treatment; later with or without $2.5 \% \mathrm{NaOCl}$ [1]. Extracted single-rooted human teeth were bisected longitudinally and the root halves $(n=100)$ were isolated with nail varnish, leaving the root canal exposed. The samples were immersed in the test solutions for 1 and 5 minutes, after which the amount of calcium ion $\left(\mathrm{Ca}^{2+}\right)$ release into the solutions was determined by flame photometry.

The calcium ions $\left(\mathrm{Ca}^{2+}\right)$ present in hydroxyapatite crystals are one of the main inorganic elements of dentin [2]. It has been reported that some chemicals used for endodontic irrigation are capable of causing alterations in the chemical composition of dentin [3-6].

\section{Methods}

Determination of calcium in the tooth's structure is very important. Calcium determination, Flame Emission Spectrofometry and inductively coupled plasma optical emission spectrometry (ICP-OES) methods can be performed. These methods can be analyzed in a short time without interference effects. In both methods, the calcium in the tooth is stimulated and the emission intensity it emits is measured as it becomes basic. These emission intensities are directly proportional to the calcium concentration. Also, in these methods, calibration graph or standard addition method is used for calcium determination.

The roots were then bisected longitudinally, and the pulp tissue was removed with a toothbrush. All root halves

\author{
More Information \\ *Address for Correspondence: Şükrü Kalaycl, \\ Department of Chemistry, Gazi University, Ankara, \\ Turkey, Email: skalayci@gazi.edu.tr \\ Submitted: 03 May 2020 \\ Approved: 14 May 2020 \\ Published: 15 May 2020 \\ How to cite this article: Kalaycı S. \\ Determination of calcium in the tooth structure by \\ using flame emission spectrophotometer. \\ J Clin Adv Dent. 2020; 4: 017-018. \\ DOI: 10.29328/journal.jcad.1001018 \\ Copyright: @ 2020 Kalaycı S. This is an open \\ access article distributed under the Creative \\ Commons Attribution License, which permits \\ unrestricted use, distribution, and reproduction \\ in any medium, provided the original work is \\ properly cited. \\ D) Check for updates \\ (1) OPEn Access
}

$(n=100)$ were dehydrated in a sterilizer at $120^{\circ} \mathrm{C}$ until they reached a fixed weight, as verified by consistent readings using a precision scale (Sartorius, Gotingen, Germany; precision $=0.0001 \mathrm{~g}$ ). Thereafter, the specimens were covered with two consecutive layers of nail varnish, leaving the root canal surface exposed.

The samples were randomly distributed into the following treatment.

Groups:

Group 1: $2.5 \% \mathrm{NaOCl}$

Group 2: 17\% EDTA

Group 3: 17\% EGTA

Group 4: 15\% EDTAC

Group 5: 1\% Tetracycline-HCl

Group 6: 17\% EDTA_2.5\% NaOCl

Group 7: 17\% EGTA_2.5\% NaOCl

Group 8: 15\% EDTAC _ 2.5\% NaOCl

Group 9: $1 \%$ Tetracycline- $\mathrm{HCl}_{-} 2.5 \% \mathrm{NaOCl}$

Group 10: Distilled water (negative control)

In each group, the specimens were immersed in a magnetic stirrer bath containing $10 \mathrm{ml}$ of test solution for 1 and 5 
minutes. In groups 1 and 10 , the same samples $(n=10)$ were used for 1- and 5-minute treatments.

Calcium is measured between 10 and 1000 ppm (mg/L) with Flame emission intensity. Calcium at a lower concentration cannot be measured.

Inductively coupled plasma optical emission spectrometry (ICP-OES) is a widely used method recently. ICP-OES is an advanced high-end method of flame emission spectrophotometer. In this method, the energy source required for excitation is provided by plasma and its temperature is between 4000 and $10000{ }^{\circ} \mathrm{C}$. There is a certain wavelength of light to which each element is stimulated. The wavelength of the light used for calcium is $455,531 \mathrm{~nm}$. At this wavelength, a calibration graph is prepared from standard solutions of calcium. Calcium in the tooth is measured using the calibration chart.

The sensitivity of this method is high. Calcium analysis in ppm (mg/L) and ppb ( $\mu \mathrm{g} / \mathrm{L})$ concentration can be analyzed with ICP-OES. In this method, the analysis takes minutes. Therefore, it is used in routine analysis.

\section{Conclusion}

Using these methods, you can easily analyze the calcium found in the structure of the tooth. Also, disinfectant like hypochlorite used during canal treatment increases the calcium release of the tooth. Therefore, the released calcium can also be analyzed using these methods. Here, each sample takes at least 5 measurements and gives the results in accordance with the scientific representation.

\section{References}

1. Sayin TC, Serper A, Cehreli ZC, Kalayci S. Calcium loss from root canal dentin following EDTA, EGTA, EDTAC, and tetracycline- $\mathrm{HCl}$ treatment with or without subsequent $\mathrm{NaOCl}$ irrigation. J Endod. 2007; 33: 581-584. PubMed: https://www.ncbi.nlm.nih.gov/pubmed/17437877

2. Marshall GW. Dentin: microstructure and characterization Quintessence Int. 1993; 24: 606-617.

PubMed: https://www.ncbi.nlm.nih.gov/pubmed/8272499

3. Hennequin M, Pajot J, Avignant D. Effects of different $\mathrm{pH}$ values of citric acid solutions on the calcium and phosphorus contents of human dentin. J Endod. 1994; 20: 551- 554.

PubMed: https://www.ncbi.nlm.nih.gov/pubmed/7643039

4. Rotstein I, Dankner E, Goldman A, Heling I, Stabholz A, et al. Histochemical analysis of dental hard tissues following bleaching. $J$ Endod. 1996; 22: 23- 26.

PubMed: https://www.ncbi.nlm.nih.gov/pubmed/8618081

5. Doğan H, Qalt S. Effects of chelating agents and sodium hypochlorite on mineral content of root dentin. J Endod. 2001; 27: 578-580. PubMed: https://www.ncbi.nlm.nih.gov/pubmed/11556562

6. Ari $\mathrm{H}$, Erdemir A. Effects of endodontic irrigation solutions on mineral content of root canal dentin using ICP-AES technique. J Endod. 2005; 31: 187-189.

PubMed: https://www.ncbi.nlm.nih.gov/pubmed/15735466 